\title{
Illocutionary Speaking Actions in Press Release Implementation of Community Activities Restrictions (PPKM) on Youtube Channel FMB9ID_IKP (Pragmatic Analysis)
}

\author{
Nur Azizah Istikoma*, Prihadi** \\ nur0040pasca.2020@student.uny.ac.i*, prihadi.uny@gmail.com** \\ Language and Art Education, Yogyakarta State University, Indonesia \\ DOI: 10.29322/IJSRP.12.01.2022.p12165 \\ http://dx.doi.org/10.29322/IJSRP.12.01.2022.p12165
}

\begin{abstract}
The objective of this research is to describe; (1) forms of illocutionary speech act, and (2) types of the illocutionary speech act in the PPKM press release on the YouTube channel FMB9ID_IKP. This research is qualitative descriptive research. The source of data in this study is the speech spoken by dr. Reisa Broto Asmoro and dr. Siti Nadia Tarmizi, M.Epid in a press release on the YouTube channel FMB9ID_IKP. The data collection technique in this study was using the free-of-charge listening technique (SBLC) and note-taking technique. The research instrument used in this research is the researcher herself or the human instruments. The validity of this research data using data triangulation. The data analysis technique of this research used the pragmatic equivalent method. Based on the data analysis carried out, two conclusions were obtained. First, the forms of illocutionary speech act found are declarative, imperative, and interrogative. Second, the types of illocutionary speech acts are found to be assertive, directive, commissive, and expressive.
\end{abstract}

Index Terms- pragmatics, speech acts, illocutions, and PPKM press releases

\section{Introduction}

Humans as social creatures, naturally will not be separated from the use of language in communication activities. Language functions as a means of communication can make it easier for a speaker to deliver a message to the interlocutor. Communication can be done using spoken, written, or in the form of signs. Through language, humans can express ideas, opinions, and thoughts that they have. In addition, successful communication can be seen by how clear the information delivery is from the speaker to the interlocutor. Therefore, it is necessary to have the ability to convey a specific purpose so that the communication point can be well achieved.

To achieve the point expressed by the speaker, the interlocutor should understand the context being discussed. Levinson [1983: 19] says that pragmatics is the study of those relations between language and context that are grammaticalized, or encoded in the structure of language or it is said that pragmatics examines the relationship between language and context in a language structure. Wijana, [1996: 2] states that pragmatics examines meaning related to context. In line with Yule's statement [1996: 3] that first, pragmatics is the study of the speaker meaning, means that here pragmatics is a science that examines the meaning of the speaker. Second, pragmatic is the study of how more gets communicated than is said, meaning that pragmatics examines the meaning communicated by the speaker implicitly conveyed to the interlocutor. Third, pragmatic is the study of contextual meaning, which means that pragmatics examines the contextual meaning of who, where, when, and what kind of situation they are facing. Fourth, pragmatic is the study of the expression of relative distance, meaning that pragmatics examines the intensity of social distance between the speaker and the interlocutor in a conversation. Mey [2001:6] also suggests that pragmatics is the study of the conditions of human language uses as these are determined by the context of society, As Leech's [1983] opinion about pragmatics that: how language is used in communication or about how language is used in communication.

One of the fields of study of pragmatics is speech acts. Rosyidi et al. [2019: 735] states that speech acts are part of language communication. Speech act is a part of pragmatic in which involves the speaker and the interlocutor and the subject being discussed. In line with the statement of Koussouhon [2016: 12] that Speech Act Theory is central to pragmatics as it deals with acts performed in making utterances, it can be said that speech acts are an important part of pragmatics in speaking. Austin [1962] in Cutting [2002:16] that speech acts are the actions performed when an utterance is produced can be analyzed on three different levels, or speech acts that can be understood based on the categorical utterances.

John R. Searle (1974) which was oriented from the thoughts of Austin in his book Speech Act: An Essay in the Philosophy of Language, suggests that there are three kinds of speech acts, including locutionary acts, actions to convey, or state something to 
provide certain information. Illocutionary acts, aside from stating something but also to do something, and perlocutionary acts, which have the power or effect to influence the interlocutor based on what the speaker wants. The most basic of the three acts is the illocutionary speech act. Rahardi [2019: 17] states that in pragmatic studies, the most frequently discussed or studied is illocutionary speech acts.

The illocutionary speech act in an utterance has a function in saying and doing something. Putrayasa [2014: 87] explaining that illocutionary speech acts are about something the speaker wants to achieve in his speech such as stating, promising, apologizing, threats, predictions, orders, pleas, etc.

Illocutionary speech acts or The Act of Doing Something based on Austin [1962], John R. Searle [1969] are classified into several types. First, assertive speech acts in which are speech acts intended to state something based on the truth of the content such as speech acts stating, suggesting, boasting, complaining, and claiming. For example, the statement As of August 2 nd, about 77,000 active cases were hospitalized, included in the speech implying that as many as 77,000 active Covid-19 patients were hospitalized. Second, directive speech acts, which are speech acts that are intended to make the interlocutor take the action based on what is intended by the speaker such as ordering, ordering, begging, advising, and recommending. For example, We urge any business practitioners to always practicing the health protocol according to the PPKM rules, included in the speech asking business practitioners to obey the PPKM rules.

Third, expressive speech acts, which are intended to express various psychological attitudes of speakers towards the situation they are facing, such as thanking, congratulating, apologizing, blaming, praising, and condoling. For example, the speech Thank you to all the people of Indonesia, covers the speech thanking all the people of Indonesia. Fourth, commissive speech acts, which are intended to state a promise or offer about something, such as speech acts of promising, swearing, and offering something. For example, the speech about The government will improve health services, was included in the speech promising to improve health services. Fifth, declarative speech acts are intended to convey speech in relevance to existing realities such as speech acts of surrendering, firing, baptizing, naming, appointing, excommunicating, and punishing. For example, the speech I will punish the fraud perpetrators, is included in the punish speech because it will punish the perpetrators of fraud.

Furthermore, to find out the illocutionary speech acts contained in the speech is by observing the spoken sentence. Nadar [2009:71] states that sentence forms are classified into three, namely declarative, interrogative, and imperative forms. Rahardi [2005: 75-77] suggests first, declarative sentences are sentences that contain notifications about something to the reader or listener. Second, interrogative sentences are sentences that contain questions about something. Third, imperative sentences are sentences that contain the order to do something.

Various forms of illocutionary speech acts can be found in various utterances, anywhere, and in any situation. In present days, the Covid-19 or Coronavirus Disease 2019 pandemic that has been occurred since the beginning of 2020 has changed all aspects of life, from religious, political, economic, socio-cultural activities, to academic activities. Various efforts have been made by the government to deal with Covid-19 pandemic cases. The government has also issued a policy of social distancing which is expected to be followed by the public. These policies include Large-Scale Social Restrictions (PSBB), Transitional PSBB, Emergency PPKM, to PPKM levels 1, 2, 3, and 4, aim to limit the movement of people to suppress the rate of transmission of Covid-19 pandemic cases. The implementation of Community Activity Restrictions (PPKM) is one of the government policies that aim to handle cases of the Covid-19 pandemic in Indonesia and is enforced in various areas identified as the point of spreading cases of the Covid-19 pandemic.

Therefore, the government also executing socialization and education regarding the restrictions on community activities. Socialization and education are expected to provide extensive information for the public extensively using social media. In accordance with the statement that the higher the number of social media users shows that more and more people are productive in communicating through social media [Setiawan et al, 90]. The number of social media users can spread the importance of information regarding the Covid-19 pandemic. One of the most used social media by Indonesian is Youtube. Youtube is a website that gives information in the form of video and various kinds of content that is accessible using the internet. social media utilization for information spreading is also used by the government to do press conferences. the press release was done periodically by inviting many sources, two of them are dr. Reisa Broto Asmoro and dr. Siti Nadia Tarmizi, M.Epid whom given responsibility by the government to educate the public regarding Covid-19. As stated by Tan [2020: 2] that The next best approach is to educate the public on the characteristics, particularly the linguistic features, of fake news, which means the best way is to educate the public. Then, Zainal [2017: 192] states that the speaker must be wise in their utterance so that it will be in accordance with the intent and can be understood by the interlocutor. Hence the need for the speaker's communication skills so the information can be accepted and understood by the public as the interlocutor regarding Covid-19 pandemic cases.

Based on the explanation, the speaker's speech, namely dr. Reisa Broto Asmoro and dr. Siti Nadia Tarmizi, M. Epid, there are utterances that show illocutionary speech acts. This research focused on the study of the speaker's speech that comprehends illocutionary speech act by reviewing the form and type of the speech act so that it can help the interlocutor in understanding the intent and purpose of the speaker's speech in conveying information.

\section{Research Methodology}

This research used qualitative type research with descriptive method. The object of this research is the speech spoken by the source person, namely dr. Reisa Broto Asmoro as spokesperson for the Covid-19 government and dr. Siti Nadia Tarmizi, M.Epid as government spokesperson for vaccination. The PPKM press release was broadcasted on the FMB9ID_IKP YouTube channel in 
August 2021. The researcher will review the form and type of the illocutionary speech act spoken by dr. Reisa Broto Asmoro and dr. Siti Nadia Tarmizi, M.Epid in a PPKM press release on the YouTube channel FMB9ID_IKP as many as three videos in August 2021.

The data collection technique used in this study was the free-of-charge listening technique (SBLC) and the note-taking technique. Then, the instrument in this research is the researcher himself or the human instrument. Researchers must evaluate how far the methods, theories, and fields are studied [Sugiyono, 105: 305-306].

The data analysis technique used in this research is the matching technique. The matching technique is a data analysis technique in which the determining tool is outside the language or not part of the language [Sudaryanto, 2015: 15]. The matching technique used in this research is the pragmatic matching technique which the determining tool is the speaker and the interlocutor.

\section{Results and Discussion}

\section{Results}

The results showed that there were forms and types of illocutionary speech act in the PPKM press release on the YouTube channel FMB9ID_IKP there were 82 speech data. First, the form of illocutionary speech acts there are three forms including declarative there are 68 speech data, interrogative there are 3 speech data, and imperative there are 11 speech data. Second, the types of illocutionary speech acts include assertive, there are 39 speech data, directive there are 24 speech data, commissive there are 3 speech data, and expressive there are 16 speech data.

Based on the focus of the study, the findings showed that there were forms and types of illocutionary speech act contained in the speech of dr. Reisa Broto Asmoro and dr. Siti Nadia Tarmizi, M.Epid in a PPKM press release on the FMB9ID_IKP YouTube channel in August 2021.

Table 1. Forms and Types of Illocutionary Speech Acts in PPKM Press Releases on FMB9ID_IKP YouTube Channel

\begin{tabular}{|c|l|c|c|c|c|c|}
\hline \multirow{2}{*}{ No. } & \multirow{2}{*}{ Form } & \multicolumn{4}{c|}{ Type } & \multirow{2}{*}{$\sum$} \\
\cline { 3 - 7 } & & Assertive & Directive & Commissive & Expressive & \\
\hline 1. & Declarative & 36 & 13 & 3 & 16 & 68 \\
\hline 2. & Interrogative & 2 & 1 & - & - & 3 \\
\hline 3. & Imperative & 1 & 10 & - & - & 11 \\
\hline \multicolumn{2}{|c|}{$\sum$} & 39 & 24 & 3 & 16 & 86 \\
\hline
\end{tabular}

\section{Discussion}

A. Forms of Illocutionary Speech Acts in PPKM Press Release on YouTube Channel FMB9ID_IKP

Based on the PPKM Press Release on the FMB9ID_IKP YouTube Channel, data on illocutionary speech acts were obtained, including declarative, interrogative, and imperative forms.

\section{Declarative}

(1) “According to last week's Covid-19 task force report, nine out of ten people in Indonesia are already wearing masks, this is good, we just have to invite the other one so that our solidarity as responsible citizens is more visible" (PPKM Press Release August 4th, 2021 by dr. Reisa Broto Asmoro).

Context of speech: the speech was spoken by dr. Reisa Broto Asmoro to the entire community by informing them that nine out of ten Indonesians have used masks.

The speech in data (1) is classified as declarative speech because the speech is spoken by dr. Reisa Broto Asmoro, as a speaker to the community as a speech opponent. The declarative speech act is a type of directive speech act because the speaker invites the interlocutor to wear a mask. Based on the data listed above, the speaker gave information that nine out of ten people in Indonesia already wear masks. This statement can also be reviewed from various aspects, in terms of the fact that most Indonesians have worn masks to protect themselves from the Covid-19 virus. In terms of form, the lingual equivalent is shown in the sentence "nine out of ten people in Indonesia are already wearing masks" which means that most Indonesians are already wearing masks. In addition, in terms of content, the speech is in the form of information provided from the Covid-19 handling task force delivered by speakers to the interlocutor that nine out of ten Indonesian people have worn masks and an invitation for all Indonesians to wear masks. Based on these aspects, it can be concluded that the speech is declarative because it contains information about the number of people who wear masks.

\section{Interrogative}

(2) "Well, I also want to explain for those who do not have a population identification number (NIK), such as groups of people with disabilities, indigenous peoples, correctional institutions, people with social welfare problems or PMKS, and Migrant Workers with Problems (PMB) that the Covid-19 vaccine service for those who do not have a NIK can be carried out together with the Department of Population and Civil Registration so that the community can be served their 
vaccination needs and their needs can be met, easier, right? indeed, that is the aim of the government to open the widest possible access to vaccination” (PPKM Press Release August 4th, 2021 by dr. Reisa Broto Asmoro).

Context of speech: the speech spoken by dr. Reisa Broto Asmoro to the whole community implying that every community has the opportunity to receive vaccination services.

The speech in data (2) is classified as interrogative speech because it was spoken by dr. Reisa Broto Asmoro, as a speaker to the community as a speech opponent. The interrogative speech act is a type of commissive speech act because the speaker offers the people who are constrained by several things as a condition to get vaccinated, as they will still receive vaccination services. This statement can also be reviewed from various aspects, in terms of the fact that the government has provided vaccine services to every Indonesian people. In terms of form, the lingual equivalent is shown in the sentence "is it easier, isn't it?" which means questioning vaccination services. In addition, in terms of content, the speech is in the form of a question asking how easy the vaccine service provided by the government is. Based on these aspects, it can be concluded that the speech is interrogative because it asks about the ease of getting vaccines.

\section{Imperative}

(3) "Therefore, we urge business practitioners who have started operating to ensure guests or visitors to always apply health protocols according to PPKM level 3 and level 4 rules" (PPKM Press Release August 4th, 2021 by dr. Siti Nadia Tarmizi, M. Epid).

Context of speech: the speech was spoken by dr. Siti Nadia Tarmizi, M.Epid to business actors who have started operations is required to apply health protocols following PPKM rules.

The utterances in data (3) are classified as imperative utterances because it was spoken by dr. Siti Nadia Tarmizi, M. Epid with the business practitioners as the speech opponent. This imperative speech act is a type of directive speech act because it invites the interlocutor to ask business practitioners to comply with government regulations by implementing health protocols. This statement can also be seen from various aspects, in terms of the fact that the government issues PPKM rules that must be obeyed by business practitioners and gives penalties to those who violate them. In terms of form, the lingual equivalent is shown in the sentence "we appeal to business practitioners" which means they must comply with the rules. In addition, in terms of content, the speech is in the form of an appeal or order to business practitioners to comply with PPKM that has been regulated by the government, namely by implementing health protocols. Based on these several aspects, it can be concluded that the speech is imperative because it orders business practitioners to obey the applicable rules.

\section{B. Types of Illocutionary Speech Acts in PPKM Press Release on YouTube Channel FMB9ID_IKP}

Based on the PPKM Press Release on the FMB9ID_IKP YouTube Channel, the types of illocutionary speech acts data were obtained, including assertive, directive, commissive, and expressive speech acts. Further explanation will be presented as follows.

\section{Assertive Speech Acts}

(4) "Ladies and gentlemen, the goal of the world health organization (WHO) is for every country to vaccinate at least $70 \%$ by the middle of next year, which include us as well" (PPKM Press Release August 4th, 2021 by dr. Reisa Broto Asmoro).

Context of speech: the speech was spoken by dr. Reisa Broto Asmoro informed the entire community that WHO's goal in mid-2022 is that every country is obliged to provide vaccine services at least $70 \%$ to its citizens.

The utterances in data (4) are classified as assertive illocutionary utterances because they are spoken by dr. Reisa Broto Asmoro, as a speaker to the community. Based on the data listed above, the speech is determined by the WHO statement regarding the purpose of vaccination stated by the speaker. The assertive statement is in the form of a declarative because it contains information about the WHO's goals in implementing vaccinations with a target that $70 \%$ of citizens have been vaccinated in each country. The speech can also be viewed from various aspects: in terms of the fact that the government is currently promoting a vaccination program for the community. In terms of form, the lingual equivalent is shown in the sentence "the goal of the WHO world health organization is" which means a statement that explains the goals of WHO. In addition, in terms of content, the speech is in the form of a speaker's statement referring to the statement of the WHO's goal which asks every country to vaccinate its citizens to achieve the target of $70 \%$ by the middle of 2022 and the government is currently implementing a vaccination program as an effort to tackle the Covid-19 pandemic in Indonesia. Based on these several aspects, it can be concluded that the utterance is an illocutionary speech act of assertive type because the utterance contains a speaker's statement which refers to the WHO statement on the spoken utterance. 


\section{Directive Speech Acts}

(5) "The government has supplied the vaccine, which now counted nearly 180 million doses and we are certainly eager to prepare ourselves to be vaccinated. So, if you're invited, let's register, deliver, and accompany our parents, family, neighbors, acquaintances" (PPKM Press Release August 4th, 2021 by dr. Reisa Broto Asmoro).

Context of speech: the speech was spoken by dr. Reisa Broto Asmoro to the entire community to vaccinate as a government effort in tackling the Covid-19 pandemic in Indonesia.

The speech in data (5) is classified in the illocutionary speech of the directive type because the speech expresses the intent of dr. Reisa Broto Asmoro, as a speaker to the community. Based on the data listed above, the speech is determined from the speech in the form of an invitation to the public to do the vaccination. The directive utterance is in the form of an imperative because it contains an invitation or request by the speaker to the interlocutor to get together with family, relatives, and acquaintances to do vaccination. This statement can also be reviewed from various aspects, in terms of the fact that since the Covid-19 pandemic, dr. Reisa Broto Asmoro always provides information and education and invites the public to try their best in dealing with the Covid-19 pandemic. In terms of form, the lingual equivalent is shown in the word "yuk" which means inviting the community to jointly carry out vaccination as an effort to protect themselves from the Covid-19 virus. In addition, in terms of content, the speech is in the form of an invitation from the speaker to get together with family, relatives, and acquaintances to do vaccination. Based on these aspects, it can be concluded that the speech is an illocutionary act of directive type because it contains an invitation to the public to vaccinate.

\section{Commissive Speech Acts}

(6) "Remember! Do not decide to self-isolate without consulting a health worker. We know that the delta variant is a variant that able to accelerates the symptoms severity, so make sure not to delay going to the hospital or health facility if the symptoms are severe or if there is an asphyxiate. Take advantage of the existing facilities if there are people who are sick, such as through the local health center or using the telemedicine facility to get advice or necessary medicines" (PPKM Press Release August 25th, 2021 by dr. Siti Nadia Tarmizi, M.Epid).

Context of speech: the speech was spoken by dr. Siti Nadia Tarmizi, M. Epid to the entire community to take advantage of the available health facilities to deal with the Covid-19 pandemic in Indonesia.

The utterances in data (6) are classified as commissive illocutionary utterances because they are spoken by dr. Siti Nadia Tarmizi, M. Epid as a speaker to the community. Based on the data listed above, the speech is determined from the speech in the form of an offer given to the public to take advantage of the health facilities provided by the government in dealing with the problems of the Covid-19 pandemic. The commissive speech is in the form of an imperative in the form of ordering the community to use health facilities. The speech can also be reviewed from various aspects, in terms of the fact that the government has provided facilities to its people, both hospital services, medicines, and so on as assistance in tackling the Covid-19 pandemic. In terms of form, the lingual equivalent is shown in the sentence "take advantage of existing facilities" which means offering various facilities provided by the government for the community. In addition, in terms of content, the speech is in the form of an offer to the public to take advantage of health facilities to cope with the Covid-19 pandemic. Based on these aspects, it can be concluded that the utterance is a commissive illocutionary speech act because the utterance contains an offer to take advantage of the health facilities provided by the government.

\section{Expressive Speech Acts}

(7) "Thank you to the citizens of Jabodetabek, Bandung, Semarang, and the surrounding of Surabaya who have worked together to reduce the risk of transmission and increase the capacity to handle Covid-19 so that the core of the word PPKM or what WHO calls be health and social measures has shown good achievement" (PPKM Press Release August 25th, 2021 by dr. Reisa Broto Asmoro).

Context of speech: the speech was spoken by dr. Reisa Broto Asmoro to all communities in several cities including Jabodetabek, Bandung, Semarang, and Surabaya who have made achievements in reducing the transmission rate of Covid-19 cases.

The utterances in data (7) are classified as illocutionary utterances of the expressive type because the utterances are expressed by dr. Reisa Broto Asmoro, as a speaker to the community in several cities. Based on the data listed above, the speech is determined from the speech in the form of a gratitude to the community for their efforts and the achievements in reducing the transmission rate of the Covid-19 pandemic. The expressive speech is in the form of a declarative because it contains the sentence "thank you" as an expression of gratitude to the citizens of Jabodetabek, Bandung, Semarang, and Surabaya who have reduced the transmission rate of the Covid-19 pandemic. This statement can also be reviewed from various aspects, in terms of the fact that the people of Jabodetabek, Bandung, Semarang, and Surabaya have made efforts and achievements in reducing the transmission rate of the Covid-19 pandemic. In terms of form, the lingual equivalent is shown in the sentence "Thank you to the citizens of Jabodetabek, Bandung, Semarang, and the surrounding of Surabaya who have worked together to reduce the risk of transmission" which means as the gratitudes expression to the community at the city 
that has participated in efforts to overcome the Covid-19 pandemic. In addition, in terms of content, the speech is in the form of gratitude to the people in the cities of Jabodetabek, Bandung, Semarang, and the surrounding of Surabaya who have made the achievement of reducing the transmission rate of the Covid-19 pandemic.

\section{Conclusion}

Based on the analysis of research data, it can be concluded that data on the forms and types of illocutionary speech acts were found in the PPKM press release on the YouTube channel FMB9ID_IKP in August 2021. The overall data found in the utterances spoken by dr. Reisa Broto Asmoro and dr. Siti Nadia Tarmizi, M. Epid as a speaker, there are 82 speech data which include the forms and types of illocutionary speech acts. First, the form of illocutionary speech acts there are three forms including declarative there are 68 speech data, interrogative there are 3 speech data, and imperative there are 11 speech data. Second, the types of illocutionary speech acts include assertive, there are 39 speech data, directive there are 24 speech data, commissive there are 3 speech data, and expressive there are 16 speech data. The forms and types of speech acts have their own characteristics.

The application or usefulness of the research results on illocutionary speech acts in the PPKM press release on the YouTube channel FMB9ID_IKP F in August 2021 in the field of learning can be used as teaching materials or references for both students and teachers. then in the readers' everyday life, it can be used to comprehend and interpret that every utterance has a specific meaning and purpose, and even has other intentions to be conveyed based on the speaker's view to the interlocutor. Thus, both speakers and interlocutors should be able to understand and convey the speech to create good communication and the communication's goals can be achieved.

\section{References}

Austin, J. L., "How to do Things with Words" Oxford: Oxford University Press, 1962.

Cutting, J., Pragmatics and Discourse. London: Routledge, 2003.

Koussouhon, L. A., "Pragmatic Analyses of President Goodluck Jonathan's Concession Speech and General Muhammadu Buhari's Acceptance Speech: A Comparative Appraisal” International Journal of Applied Linguistics \& English Literature. Australia, vol 5[4], pp 12-19, 2016.

Leech, Geoffrey, "Principles of Pragmatics" London: Longman, 1983.

Levinson, S. C, "Pragmatics" Cambridge: Cambridge University Press, 1983.

Mey, L. J., "Pragmatics: an Intoduction" Oxford: Blackwell Publisher Ltd, 2001.

Nadar, F.X., "Pragmatik dan Penelitian Pragmatik" Yogyakarta: Graha Ilmu, 2009.

Putrayasa, I. B., "Pragmatik". Yogyakarta: Graha Ilmu, 2014.

Rahardi, K., "Pragmatik: Kesantunan Imperatif Bahasa Indonesia" Jakarta: Erlangga, 2005.

Rahardi, K., "Sosiopragmatik." Jakarta: Erlangga, 2009.

Rosyidi, A. Zuhri, et al. "Illocutionary Speech Acts Use by Jokowidodo in First Indonesia Presidential Election Debate 2019" International Journal of Multicultural and Multireligious Understanding. Indonesian, vol. 4[2], pp 735-740, 2019.

Sudaryanto, "Metode dan Aneka Teknik Analisis Bahasa" Yogyakarta: Duta Wacana University Press, 2015.

Sugiyono, "Metode Penelitian Pendidikan Pendekatan Kuantitatif, Kualitatif, dan R\&D" Bandung: Alfabeta, 2015.

Searle, J. R. "Studies in the Theory of Speech Act: expression and meaning" Cambridge: Cambridge University Press, 1974.

Setiawan, Anang, et al., "Efektifitas Penyebaran Informasi Covid-19 Melalui Media Twitter Kementrian Kesehatan Republik Indonesia dan Badan Nasional Penanggulangan Bencana" Yogyakarta: Jurnal Academia Praja" Indonesian, vol 4[1], 89-106, 2021.

Tan, K. H, et al., "Covid-19 Insights and Linguistic Methods" 3L: The Southeast Asian Journal of English Language Studies, Malaysia, vol. 26[2], pp 1-23, 2021.

Wijana, I Dewa Putu, "Dasar-dasar Pragmatik" Yogyakarta: Andi, 1996.

Yule, George, Pragmatics. Oxford: Oxford University Press, 1996.

Yule, G., "Pragmatik" Yogyakarta: Pustaka Pelajar, 2006.

Zainal, M. Z., 'Teacher's Illocutionary Act in Teaching Malay Language” GEMA Online ${ }^{\circledR}$ Journal of Language Studies. Malaysia, vol. 17[4], pp 91-208, 2017.

\section{Author}

First Author - Nur Azizah Istikoma, Language and Art Education, Yogyakarta State University, Indonesia; nur0040pasca.2020@student.uny.ac.id

Second Author - Dr. Drs. Prihadi, M.Hum, Language and Art Education, Yogyakarta State University, Indonesia; prihadi.uny@gmail.com

Correspondence Author - Nur Azizah Istikoma, Language and Art Education, Yogyakarta State University, Indonesia; nur0040pasca.2020@student.uny.ac.id, +6285392051845 